\title{
PE hospital turmoil: CEO leaves, nurses snore in patient beds
}

\begin{abstract}
Longstanding critical staff shortages in the maternity unit at Port Elizabeth's Dora Nginza Hospital came to a head in midFebruary with a 3-day nurses' strike, the enforced departure of the CEO, and nearly burnt-out doctors being prevented from doing ward rounds by strikers.

Official documents in the possession of Izindaba reveal doctor allegations of leadership autocracy, major staff shortages, non-appointment of consultants to available posts, outstanding overtime payments, lack of academic support and burn-out. Combined, the doctors claim, these conditions have led to patient care being compromised, which was aggravated by the nurses' strike from 10 to 12 February. At least one pregnant woman died during the strike, although Izindaba could not establish whether or not this was due to strike-compromised care. Eight doctors per shift were covering a 60-bed antenatal ward, a 70-bed postnatal ward, a 43-bed gynaecological ward, an 18-bed high-care unit, a 9-bed labour ward, a 4-bed observation ward and a teeming outpatient clinic - around the clock. The unresolved issues led to major differences between the maternity unit chief Dr Mfundo Mabenge, a member of the National Committee for the Confidential Enquiries into Maternal Deaths (the 'Saving Mothers, Saving Babies' committee), and his CEO, Dr Nthombi Quangule. These came to a head, said Izindaba sources in both Bisho (the provincial health department head office) and at the hospital, when Quangule sent an ambulance to fetch Mabenge from his home after he took a few days off to relieve burn-out.
\end{abstract}

\section{Surprise visit catches nurses asleep in ward beds}

Then, just days before the strike, Quangule, in an unannounced late-night medical ward inspection, surprised eight nurses - the entire complement for the ward - asleep in unoccupied patient beds. A disciplinary hearing was pending at the time of going to print, Bisho confirmed. The Eastern Cape health department also began a probe into Quangule's 'autocratic' behaviour and her alleged lack of response to doctor complaints, temporarily relieving her of her post. The probe findings, which would lead either to her return to her post or the continuation of her temporary replacement, Dr Bawinile Ndlovu, were due at the end of February. All the worker unions involved (the National Education, Health and Allied Workers' Union (NEHAWU), the Health \& Other Services Personnel Trade Union of South Africa (HOSPERSA) and the Democratic Nursing Organisation of South Africa (DENOSA)) called for Quangule's sacking after a high-level Bisho delegation and a local parliamentary portfolio committee visited the hospital, promising to rectify matters with a detailed plan of action. Quangule was then advised to stay away for her own safety.

\section{Factors contributing to the hospital crisis included the inefficient use of staff and a recent major growth in services. The latter was prompted by a new system decanting patients from other districts to Dora Nginza Hospital before a new staffing plan could be implemented.}

Izindaba doctor sources said the stalled appointment of senior doctors in the obstetrics and gynaecology unit was leading to senior doctors being overburdened because they had to perform all the caesarean sections (junior doctors may not operate independently). On average, 800 babies are born at the hospital each month. The doctors said that plans for training, and better equipment at clinic level, were abandoned owing to budget constraints. Izindaba is in possession of a letter, dated 4 January 2015, from Dr Lungile Pepeta, paediatrics chief at Dora Nginza Hospital, and addressed to the entire provincial health leadership. In it he said that the Port Elizabeth Hospital Complex was being prevented from replacing medical staff who had left the department during the previous 3 months. 'The department has issued circulars stating that the appointment of staff will be centralised and that there will no replacement of Medical officer posts that have been vacated in order for them to take up funded registrar posts - this has placed unbearable strain in the system.' Pepeta went on to cite post-community service officers who wanted to remain in the hospital complex not being absorbed.

\section{Hospital accreditation in danger, chief warns}

Pepeta warned that with a Health Professions Council of South Africa training accreditation inspection due in February, several departments, including cardiothoracic surgery, obstetrics and gynaecology and psychiatry, stood to lose their training status. He expressed shock at the 'ongoing notion by the provincial leadership' that specialist numbers were sufficient, when in fact they were worse than the doctorpopulation ratios of several low-income African countries. One estimate puts the Eastern Cape doctor/patient ratio at one doctor per 10000 people (ten times less than the World Bank prescription of 1/1 000 people). Speaking to Izindaba, a spokesman for the provincial health department, Siyanda Manana, denied that any moratorium on filling posts existed, saying the procedure was to identify a critical post and then write a motivation to the Cost Containment Committee, which sat weekly. He stressed that the post needed already to have had funding allocated to it. The CEO, Quangule, could not be blamed for this, he added. Factors contributing to the hospital crisis included the inefficient use of staff and a recent major growth in services. The latter was prompted by a new system decanting patients from other districts to Dora Nginza Hospital before a new staffing plan could be implemented. Everything possible would be done to retain longstanding and highly valued staff, he added.

Union spokespersons declined to comment until the probe and disciplinary hearing were completed.

\section{Chris Bateman}

chrisb@hmpg.co.za

S Afr Med J 2016;106(4):320

DOI:10.7196/SAMJ.2016.v106i4.10763 